\title{
Pengaruh Jumlah Uang Beredar dan Kurs terhadap Harga Beras di Indonesia dengan Inflasi sebagai Variabel Intervening
}

\section{The Effects of Money Supply and Exchange Rate on Rice Prices in Indonesia with Inflation as Intervening Variable}

\author{
Muhammad Syariful Anam ${ }^{1)}$, Dian Luthvita Nadila ${ }^{2)}$, Iskandar Iskandar ${ }^{3)}$ \\ ${ }^{1,2,3)}$ Fakultas Ekonomi dan Bisnis Islam, IAIN Salatiga, Kota Salatiga \\ e-mail korespondensi: syarifulanam2700@gmail.com
}

\begin{tabular}{|c|c|}
\hline Info Artikel & Abstrak \\
\hline $\begin{array}{l}\text { Riwayat Artikel: } \\
\text { Diterima: } 19 \text { Juni } 2020 \\
\text { Disetujui: } 06 \text { Februari } 2021 \\
\text { Dipublikasikan: Juli } 2021\end{array}$ & $\begin{array}{l}\text { Penelitian ini bertujuan untuk mengetahui pengaruh jumlah uang beredar dan } \\
\text { kurs terhadap harga beras dengan inflasi sebagai variabel intervening. Data data } \\
\text { sekunder bersifat time series periode } 2015-2019 \text { dari BPS dan BI, dan dianalisis } \\
\text { menggunakan model analisis jalur yang merupakan perluasan dari regresi linier }\end{array}$ \\
\hline $\begin{array}{l}\text { Nomor DOI } \\
\text { 10.33059/jseb.v12i2.2429 } \\
\text { Cara Mensitasi : } \\
\text { Anam, M. S., Nadila, D. L., \& } \\
\text { Iskandar, I. (2021). Pengaruh } \\
\text { jumlah uang beredar dan kurs } \\
\text { terhadap harga beras di } \\
\text { Indonesia dengan inflasi } \\
\text { sebagai variabel intervening. } \\
\text { Jurnal Samudra Ekonomi dan } \\
\text { Bisnis, 12(2), 168-183. doi: } \\
\text { 10.33059/jseb.v12i2.2429. }\end{array}$ & $\begin{array}{l}\text { berganda. Hasil penelitian menunjukan bahwa jumlah uang beredar berpengaruh } \\
\text { negatif dan signifikan terhadap inflasi, sementara kurs berpengaruh positif dan } \\
\text { tidak signifikan terhadap inflasi. Temuan yang lain adalah jumlah uang beredar } \\
\text { diidentifikasi berpengaruh positif dan signifikan terhadap harga beras, kurs } \\
\text { berpengaruh negatif dan tidak signifikan terhadap harga beras, dan inflasi } \\
\text { berpengaruh negatif dan signifikan terhadap harga beras. Temuan ketiga bahwa } \\
\text { inflasi sebagai variabel intervening hanya memediasi jumlah uang beredar } \\
\text { terhadap harga beras. } \\
\text { Kata Kunci: Jumlah Uang Beredar, Kurs, Harga Beras, Inflasi. }\end{array}$ \\
\hline
\end{tabular}

\begin{tabular}{|c|c|}
\hline Article Info & Abstract \\
\hline $\begin{array}{l}\text { Article History: } \\
\text { Received: } 19 \text { June } 2020 \\
\text { Accepted: } 06 \text { February } 2021 \\
\text { Published: July } 2021\end{array}$ & $\begin{array}{l}\text { The study aims to determine the effect of the money supply and exchange rates } \\
\text { on rice prices with inflation as an intervening variable. Secondary data is time } \\
\text { series 2015-2019 from BPS and BI, and is analyzed using a path analysis model } \\
\text { which is an extension of multiple linear regression. The results showed that the }\end{array}$ \\
\hline $\begin{array}{l}\text { DOI Number: } \\
\text { 10.33059/jseb.v12i2.2429 } \\
\text { How to cite : } \\
\text { Anam, M. S., Nadila, D. L., \& } \\
\text { Iskandar, I. (2021). Pengaruh } \\
\text { jumlah uang beredar dan kurs } \\
\text { terhadap harga beras di } \\
\text { Indonesia dengan inflasi } \\
\text { sebagai variabel intervening. } \\
\text { Jurnal Samudra Ekonomi dan } \\
\text { Bisnis, 12(2), 168-183. doi: } \\
\text { 10.33059/jseb.v12i2.2429. }\end{array}$ & $\begin{array}{l}\text { money supply had a negative and significant effect on inflation, while the } \\
\text { exchange rate had a positive and insignificant effect on inflation. Another } \\
\text { finding is that the money supply has a positive and significant effect on rice } \\
\text { prices, the exchange rate has a negative and insignificant effect on rice prices, } \\
\text { and inflation has a negative and significant effect on rice prices. The third } \\
\text { finding is that inflation as an intervening variable only mediates the money } \\
\text { supply to the price of rice. } \\
\text { Keywords: Money Supply, Exchange Rate, Rice Prices, Inflation. }\end{array}$ \\
\hline
\end{tabular}




\section{PENDAHULUAN}

Negara dengan tingkat konsumsi beras dalam jumlah besar adalah Indonesia, dimana sebagian besar masyarakatnya mengonsumsi beras pada setiap harinya sebagai sumber karbohidrat utama. Indonesia dengan populasi penduduk terbesar keempat di dunia merupakan salah satu aspek tingginya tingkat permintaan terhadap bahan pangan terutama beras (Rahmanta \& Maryunianta, 2020). Tingkat konsumsi rata-rata masyarakat atas beras berdasarkan pengamatan Kementerian Perdagangan yaitu antara 130-140kg/orang setiap tahun. Konsumsi beras di Indonesia bukan hanya terfokus pada kebutuhan rumah tangga, namun juga digunakan sebagai bahan baku industri seperti tepung beras atau bahan makanan lainnya (Namira et al., 2017). Tingginya tingkat permintaan terhadap komoditi beras mengharuskan pemerintah untuk bisa menyeimbangkan penawaran beras yang tersedia di pasar.

Produksi beras di Indonesia mengalami peningkatan yang tidak signifikan setiap tahunnya, sehingga belum mampu untuk memenuhi kebutuhan beras masyarakat skala nasional yang mencapai 237 juta jiwa dengan persentase tingkat pertumbuhan penduduk yang meningkat setiap tahunnya. Produksi beras Indonesia pada tahun 2019 mengalami penurunan. Berdasarkan data dari Badan Pusat Statistik sebesar 31,31 juta ton di tahun tersebut dimana pada tahun sebelumnya berhasil memproduksi sebanyak 33,94 juta ton, padahal tingkat cadangan beras yang harus dimiliki negara di Perum BULOG tercatat rata-rata antara 750-1.25 juta ton. Ketersediaan beras yang tidak memadai itulah mengharuskan pemerintah untuk mengambil kebijakan impor beras untuk menutup kekurangan cadangan beras di Indonesia.

Kegiatan pemenuhan penawaran atas permintaan beras di pasar menimbulkan berbagai persoalan dimana salah satunya adalah harga beras, terlebih hampir sebagian besar pemenuhan ketersediaan beras negara diperoleh dari kegiatan impor. Harga beras menjadi salah satu aspek yang mendapat perhatian khusus oleh pemerintah yang termaktub dalam kebijakan pangan negara. Analisis kebijakan pangan mempunyai peran utama dalam merangkai suatu program yang menghubungkan antara masalah lingkungan mikro dan makro dengan tujuan untuk pertumbuhan yang lebih cepat. Instrumen kebijakan harga yang pernah ditetapkan oleh pemerintah adalah dengan penetapan harga dasar gabah (HDG), dimana kebijakan tersebut mampu memberikan jaminan harga wajar terhadap petani sehingga dapat meningkatkan produksi dan juga memberikan perlindungan harga beli untuk konsumen atau masyarakat. Namun karena kebijakan harga dasar gabah (HDG) dianggap tidak efektif seiring peningkatan volume impor beras, maka pemerintah mulai mengganti kebijakan dengan model penetapan harga pembelian pemerintah (HPP) yang merupakan transisi menuju pelepasan harga gabah ke pasar (Saputra et al., 2014).

Pada periode tahun 2015-2019 tingkat harga beras di Indonesia terus mengalami peningkatan. Perkembangan harga beras di Indonesia periode 2015-2019 dapat dilihat pada Gambar 1. Berdasarkan gambar tersebut, perkembangan harga beras di Indonesia pada tahun 2015-2019 cenderung mengalami peningkatan dimana tercatat di tahun 2015 harga beras sebesar Rp. 11.465,- kemudian mengalami kenaikan menjadi Rp. 11.476,pada tahun 2016. Sedangkan pada tahun 2017 harga beras mengalami kenaikan signifikan yaitu mencapai angka Rp. 11.838,-. Harga beras pada tahun 2018 kembali mengalami kenaikan mencapai Rp. 12.106,- dan tidak mengalami kenaikan yang cukup signfikan pada tahun 2019 di level Rp. 12.183,-. 


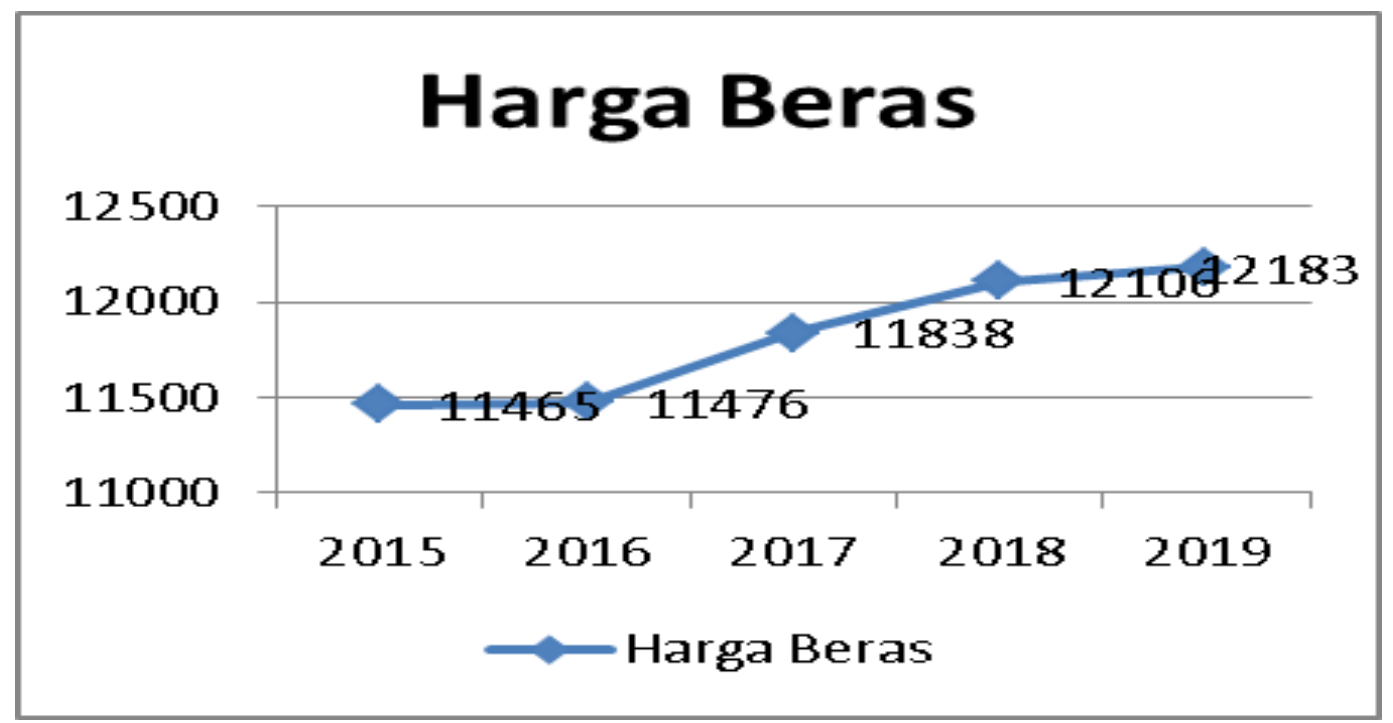

Gambar 1. Tren Harga Beras di Indonesia Periode 2015 - 2019

Sumber: Badan Pusat Statistik, 2020.

Karenanya, berdasarkan Gambar 1, dapat dinyatakan bahwa selama periode 20152019 diidentifikasi harga beras tercatat mengalami peningkatan setiap tahunnya; dimana pada tahun 2015 berada pada angka Rp. 11.465,- mencapai level harga Rp. 12.183,- di tahun 2019. Secara kuantitas, grafik harga beras di Indonesia dari tahun ke tahun tersebut bergerak semakin ke atas.

Salah satu faktor yang dinilai dapat mempengaruhi harga beras adalah jumlah uang yang beredar. Pada teori kuantitas uang yang dikemukakan oleh David Ricardo bahwa semakin banyak jumlah uang beredar mengakibatkan penurunan nilai mata uang itu sendiri. Kondisi tersebut terjadi apabila jumlah uang yang beredar bertambah namun barang yang tersedia atau ditawarkan tetap jumlahnya, sehingga mengakibatkan tingkat permintaan masyarakat juga mengalami peningkatan diikuti dengan peningkatan harga barang (Nopirin, 2000).

Pasokan beras nasional Indonesia terbanyak adalah berasal dari kegiatan impor. Oleh karenanya, faktor lain yang bisa memicu naiknya harga beras adalah kurs rupiah terhadap dollar. Nilai tukar atau kurs adalah harga mata uang suatu negara terhadap mata uang negara lain (Eiteman, 2010; Adhawiyah et al., 2018). Kegiatan impor merupakan satu bentuk perdagangan internasional, sehingga mata uang yang digunakan dengan mata uang asing (dollar) sebagai alat pembayaran. Ketika nilai dari mata uang rupiah mengalami depresiasi terhadap mata uang dolar maka akan terjadi kenaikan harga beli barang impor yang kemudian akan berpengaruh terhadap harga jual barang di pasar domestik.

Kenaikan atau penurunan harga di berbagai komoditi pangan, salah satunya beras juga bisa dipengaruhi karena terjadinya inflasi pada perekonomian negara. Salah satu sebab terjadinya inflasi adalah depresiasi nilai mata uang atau kurs terhadap mata uang internasional. Lonjakan angka inflasi juga memberi pengaruh buruk terhadap stabilitas perekonomian (Perlambang, 2012). Indonesia pernah mengalami hiperinflasi mencapai $\pm 600 \%$ pada tahun 1965 tepatnya pada masa pemerintahan Presiden Soekarno. Kemudian di tahun 1998 ketika terjadi krisis moneter, Indonesia kembali mengalami inflasi tinggi yaitu mencapai $\pm 77 \%$; akibatnya masyarakat ikut merasakan dampak negatif dari tingginya inflasi tersebut. Peningkatan laju inflasi yang tinggi tahun 1998 disebabkan oleh pelemahan 
nilai tukar rupiah (depresiasi). Oleh karena itu, laju inflasi di Indonesia harus tetap dapat dikendalikan sebaik mungkin supaya tingkat kesejahteraan hidup masyarakat tidak mengalami penurunan.

Usaha untuk membuat laju inflasi bertahan di angka yang rendah dapat dengan penekanan harga melalui penekanan jumlah uang yang beredar, sebagai contoh dengan penahanan pemberian kredit atau menaikkan suku bunga pinjaman (Perlambang, 2012). Oleh sebab itu, dalam rangka menjaga harga komoditas pangan agar tidak melambung, diperlukan peningkatan pengendalian pada berbagai sektor yang dipandang menjadi pemicu meningkatnya angka inflasi oleh Bank Indonesia, Pemerintah Pusat dan Pemerintah Daerah (Saputra et al., 2014). Berdasarkan pemikiran ini, penelitian ini bertujuan menganalisis pengaruh jumlah uang beredar, kurs terhadap harga beras di Indonesia pada periode 2015-2019 dengan inflasi sebagai variabel intervening.

\section{Jumlah Uang Beredar dan Inflasi}

Uang merupakan alat tukar yang digunakan untuk melakukan transaksi jualbeli baik barang, jasa, maupun utang. Teori Kuantitas memaparkan penyebab inflasi yaitu penambahan jumlah uang beredar serta ekspektasi masyarakat mengenai kenaikan harga-harga. Ketika bank sentral tidak menambahkan volume uang yang beredar, kenaikan harga terjadi hanya untuk sementara waktu. Dengan kata lain, inflasi akan berhenti dengan sendirinya (Rahmawati et al., 2017).

Beberapa hasil penelitian terdahulu menunjukkan bahwa jumlah uang beredar mempunyai pengaruh signifikan terhadap angka inflasi (Maune et al., 2020; Jumhur et al., 2018; Mbongo et al., 2014). Berdasarkan hasil-hasil tersebut, maka dalam penelitian ini dimunculkan hipotesis yang pertama:
H1: Jumlah uang beredar berpengaruh signifikan terhadap inflasi di Indonesia periode 2015-2019.

\section{Kurs dan Inflasi}

Kurs merupakan perbandingan nilai suatu mata uang dengan mata uang milik negara lain (Mahendra, 2016). Keseimbangan nilai mata uang suatu negara dapat tercermin dari tingkat permintaan dan penawaran terhadap nilai tukar itu sendiri. Tingkat harga berperan dalam aktivitas kurs karena berfungsi sebagai penyeimbang antara jumlah uang beredar dengan jumlah permintaan uang. Ketika Bank Sentral menambahkan jumlah uang yang beredar maka akan menyebabkan tingkat harga juga meningkat, dan hal tersebut berdampak pada depresiasi mata uang suatu negara terhadap mata uang negara lain.

Penelitian yang dilakukan Rahadyan \& Lubis (2018), Ningsih \& Kristiyanti (2018), serta Larasati \& Amri (2017), memperoleh hasil bahwa kurs mempunyai pengaruh signifikan terhadap inflasi. Berdasarkan teori serta hasil-hasil penelitian terdahulu, maka dimunculkan hipotesis yang kedua:

H2: Kurs berpengaruh signifikan terhadap inflasi di Indonesia periode 2015-2019.

\section{Harga Beras dan Jumlah Uang Beredar}

Level harga beras memiliki keterkaitan dengan peredaran jumlah mata uang. Ketika jumlah uang yang beredar di masyarakat lebih besar dibandingkan persediaan barang yang ada dalam pasar, mengakibatkan terjadinya kelebihan uang oleh masyarakat yang diiringi dengan meningkatnya permintaan terhadap suatu barang atau jasa. Apabila jumlah permintaan tidak diseimbangkan dengan jumlah persediaan barang yang ada di pasar, maka hal ini akan mengakibatkan peningkatan harga pada suatu barang. Penawaran uang kepada masyarakat harus disesuaikan dengan kebutuhan atau permintaannya. Ketika uang 
yang ditawarkan lebih banyak dibandingkan dengan kebutuhan atau permintaannya maka akan memicu terjadinya kenaikan harga suatu komoditi, salah satunya adalah beras yang merupakan komoditas pangan utama di Indonesia.

Studi terdahulu yang dilakukan oleh Browne \& Cronin (2010) serta Faris (2016) tentang harga komoditas domestik menghasilkan temuan bahwa terdapat pengaruh antara jumlah uang beredar (JUB) atas perubahan harga dari komoditas domestik. Berdasarkan argumen-argumen itu maka dimunculkan hipotesis ketiga:

H3: Jumlah uang beredar berpengaruh signifikan terhadap harga beras di Indonesia periode 2015-2019.

\section{Harga Beras dan Kurs}

Tingkat harga beras juga dipandang dipengaruhi oleh nilai tukar rupiah terhadap dollar sebagai mata uang dunia. Mengingat sebagian besar pasokan beras Indonesia didapatkan melalui kegiatan impor dikarenakan belum mampu terpenuhinya produksi beras dalam negeri. Pada saat nilai tukar rupiah terhadap dollar mengalami depresiasi atau nilainya melemah maka menyebabkan biaya impor barang ke dalam negeri lebih mahal, yang kemudian berimbas pada kenaikan harga barang di pasar. Diperlukan peran Bank Sentral untuk melakukan langkah antisipasif dalam menjaga stabilitas perekonomian, khususnya nilai tukar rupiah melalui penerapan kebijakan moneter yang tepat dan konsisten. Kestabilan dan peningkatan nilai tukar rupiah atas dolar tentunya berpengaruh terhadap derajat kesejahteraan masyarakat dikarenakan perekonomian berjalan dengan baik termasuk tingkat harga pada berbagai komoditas.

Studi yang dilakukan oleh Malian et al. (2004) serta Suarsih et al. (2016) menyatakan bahwa terdapat pengaruh signfikan antara kurs atau nilai tukar terhadap harga beras di pasar domestik. Rezitis (2015) serta Gilbert (2010) dalam penelitian mereka mengenai harga komoditas pertanian memperoleh temuan bahwa terdapat pengaruh signifikan antara nilai tukar atau kurs atas perubahan harga komoditas pertanian. Berdasarkan hasil atau temuan penelitian terdahulu itu maka dimunculkan hipotesis keempat:

H4: Kurs berpengaruh signifikan terhadap harga beras di Indonesia periode 20152019.

\section{Harga Beras dan Inflasi}

Depresiasi mata uang yang ekstrim dapat memicu terjadinya krisis keuangan pada suatu negara dengan ditandainya kenaikan angka inflasi (Putra, 2017). Kondisi tersebut menimbulkan berbagai permasalahan perekonomian utamanya pada aktifitas produksi, ekspor, serta tingkat impor yang mengalami penurunan tingkat efisiensi sehingga berikutnya menyebabkan barang-barang domestik mengalami kenaikan harga karena penawaran barang di pasar.

Penelitian yang dilakukan Muljawan \& Alibaba (2009) menemukan bahwa terdapat pengaruh antara inflasi terhadap harga beras. Berdasarkan argumen itu maka dimunculkan hipotesis kelima:

H5: Inflasi berpengaruh signifikan terhadap harga beras di Indonesia periode 20152019.

\section{Jumlah Uang Beredar, Kurs, Inflasi, dan Harga Beras}

Penelitian ini juga bertujuan untuk menghubungkan antara variabel independen yaitu jumlah uang beredar dan kurs, inflasi sebagai variabel intervening, serta variabel dependen yaitu harga beras. Karenanya dalam penelitian ini dimunculkan hipotesis keenam dan ketujuh, yaitu: 
H6: Inflasi sebagai variabel mediasi antara jumlah uang beredar dan harga beras di Indonesia periode 2015-2019.

H7: Inflasi sebagai variabel mediasi antara kurs dan harga beras di Indonesia periode 2015-2019.
Berdasarkan hipotesis-hipotesis yang telah dipaparkan, maka kerangka pemikiran dalam penelitian ini dapat diperlihatkan pada Gambar 2.

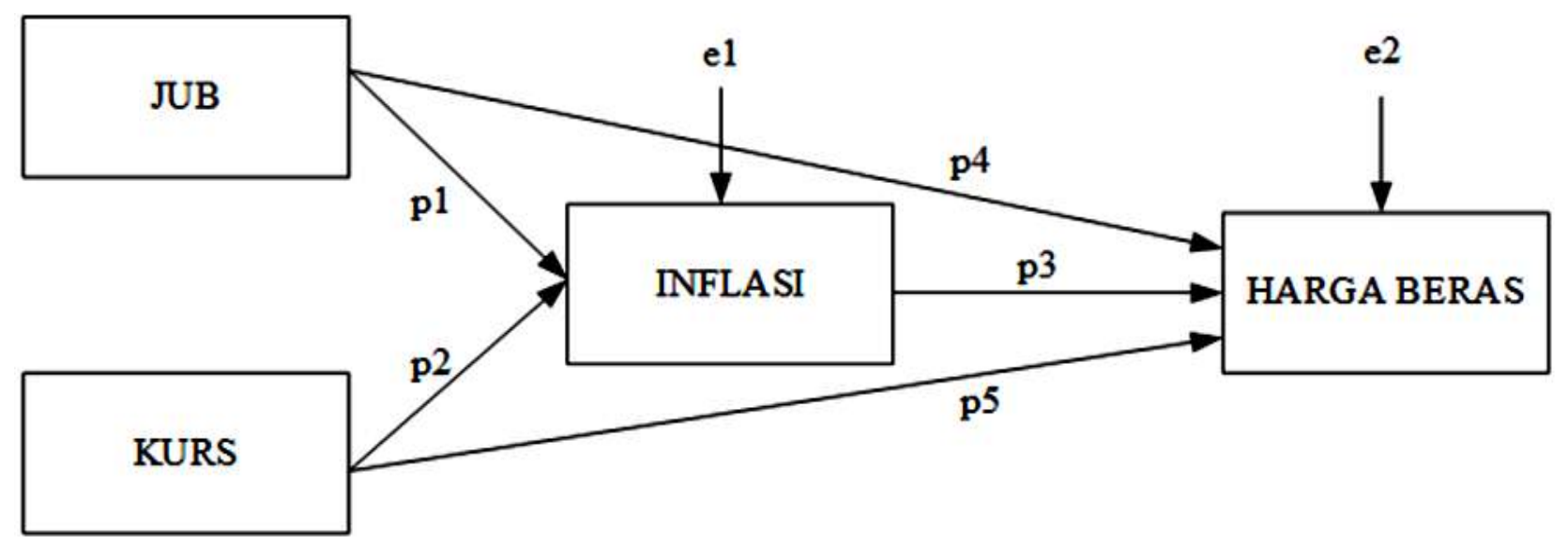

\section{Gambar 2. Kerangka Penelitian}

Sumber: Diolah penulis, 2020.

\section{METODE PENELITIAN}

Paradigma dalam penelitian ini adalah positivisme sehingga menggunakan metode kuantitatif. Sumber data sekunder merupakan data runtut waktu (time series) tahun 20152019 yang diperoleh dari hasil laporan publikasi BPS dan BI, serta dari beberapa dokumentasi yang berhasil dihimpun oleh peneliti (Radjab \& Jam’an, 2017).

\section{Definisi Operasional Variabel}

Penelitian ini mencakup dua variabel independen, satu variabel dependen, dan satu variabel intervening. Definisi operasional dari masing-masing variabel tersebut dijelaskan sebagai berikut.

Variabel independen pertama adalah jumlah uang beredar $\left(\mathrm{X}_{1}\right)$. Kewajiban sistem moneter yang bisa menggambarkan likuiditas perekonomian adalah jumlah uang beredar (M2). Komponen-komponen uang beredar dalam cakupan yang lebih luas meliputi uang kartal, uang giral, uang kuasi serta surat berharga. Data yang digunakan adalah data jumlah uang beredar bulanan dalam bentuk miliaran rupiah tahun 2015-2019, berasal dari laporan Statistik Ekonomi Keuangan Indonesia BI.

Variabel independen kedua yaitu kurs $\left(\mathrm{X}_{2}\right)$. Kurs merupakan perbandingan nilai mata uang dalam negeri yang diukur dengan nilai mata uang asing. Untuk data yang digunakan yaitu kurs tengah rupiah per dollar AS atau IDR/USD bulanan dalam satuan rupiah tahun 2015-2019 yang diperoleh dari hasil publikasi $\mathrm{BI}$.

Berikutnya, variabel dependen adalah harga beras (Y). Harga beras merupakan faktor yang dapat dijadikan sebagai tolok ukur untuk menstabilkan perekonomian. Jika terjadi kenaikan harga beras tentu akan sangat berpengaruh terhadap sisi permintaan dan penawaran. Data yang dipakai yaitu harga beras bulanan dalam satuan rupiah tahun 2015-2019 yang diperoleh dari hasil publikasi milik BPS. 
Variabel terakhir adalah inflasi sebagai intervening $\left(\mathrm{X}_{3}\right)$. Inflasi merupakan fenomena yang umum terjadi dalam perekonomian, dimana harga-harga barang serta jasa mengalami kenaikan dalam satu periode tertentu dan relatif lama. Dalam hal ini, penghitungan laju inflasi menggunakan IHK. Data yang digunakan adalah nilai inflasi bulanan dalam satuan persen tahun 2015-2019 dari hasil publikasi BPS serta laporan BI.

\section{Metode Analisis Data}

Metode analisis dilakukan melalui beberapa prosedur. Prosedur pertama yaitu data harus memenuhi asumsi klasik yang mencakup uj-uji autokorelasi, multikolinieritas, normalitas dan heteroskedastisitas. Prosedur kedua yaitu uji individual (parsial) yang diproses dengan menggunakan uji $t$, serta uji serentak (simultan) yang dilakukan melalui uji $F$, untuk menguji model secara keseluruhan (Suharjo, 2013).

Prosedur ketiga adalah teknik analisis jalur (path analysis), sebagai perluasan dari regresi linier berganda yang digunakan untuk menentukan hubungan kausalitas antar variabel yang ditetapkan (Ghozali, 2018). Analisis jalur dilakukan melalui dua tahap, yaitu: (1) pertama menguji pengaruh jumlah uang beredar dan kurs terhadap inflasi, dan (2) menguji pengaruh jumlah uang beredar, kurs dan inflasi terhadap harga beras. Jalur hubungan antar variabel dapat dilihat pada Gambar 2, dengan persamaan matematis:

$$
\begin{aligned}
& X_{3}=\beta_{0}+\beta_{1} X_{1}+\beta_{2} X_{2}+e_{1} \\
& Y=\beta_{0}+\beta_{1} X_{1}+\beta_{2} X_{2}+\beta_{3} X_{3}+e_{2}
\end{aligned}
$$

dimana $\mathrm{Y}$ adalah harga beras; $\beta_{0}$ adalah konstanta; $\beta_{1}$ sampai $\beta_{3}$ adalah koefisien korelasi dari tiap-tiap variabel independen serta intervening; $X_{1}$ adalah jumlah uang beredar; $\mathrm{X}_{2}$ adalah kurs; $\mathrm{X}_{3}$ adalah inflasi; serta, $\mathrm{e}_{1}$ dan $\mathrm{e}_{2}$ adalah Error term sub struktur 1 dan 2 .
Prosedur uji statistik dari penelitian ini adalah uji Sobel. Uji sobel digunakan untuk mengukur efek tidak langsung dari variabel bebas terhadap variabel terikat dengan melalui variabel pemediasi (Hayes, 2009). Formula dari uji Sobel adalah (Ghozali, 2018):

$$
S a b=\sqrt{b^{2} S a^{2}+a^{2} S b^{2}+S a^{2} S b^{2}}
$$

dimana $\mathrm{Sab}$ adalah standar error pengaruh tidak langsung; $a$ adalah jalur $\mathrm{X}_{1}$ dan $\mathrm{X}_{2}$ ke $\mathrm{X}_{3} ; b$ adalah jalur $\mathrm{X}_{3}$ ke $\mathrm{Y}$; Sa adalah standar error koefisien $a$; serta $S b$ adalah standar error koefisien $b$.

Untuk menguji signifikansi pengaruh tidak langsung, terlebih dahulu menghitung nilai $t$ dari koefisien $a b$ menggunakan rumus:

$$
\mathrm{t}=\frac{a b}{5 a b}
$$

Apabila nilai $t$-hitung tersebut telah diketahui, selanjutnya dibandingkan dengan nilai $t$-tabel. Jika nilai $t$-hitung lebih besar dari $t$-tabel, maka disimpulkan terjadi pengaruh mediasi.

\section{HASIL ANALISIS \\ Hasil Statistik Deskriptif}

Berdasarkan hasil output (Tabel 1), diidentifikasi secara deskriptif bahwa dari tahun 2015-2019 harga beras terendah sebesar Rp. 10.569,- dan harga tertinggi sebesar Rp. 12.414,- sedangkan untuk rata-ratanya sebesar Rp. 11.621,40,- dengan standar deviasi sebesar Rp. 465,955,- Berikutnya, jumlah uang beredar terendah sebesar Rp. 4.174.825,91 miliar dan tertinggi sebesar Rp. 6.136.552 miliar, sementara nilai rata-rata sebesar Rp. 5.127.984,62 miliar dengan standar deviasi Rp. 575.769,20 miliar.

Nilai kurs terendah selama tahun 20152019 sebesar Rp. 12.625,- dan tertinggi sebesar Rp. 15.227,- sedangkan rata-ratanya sebesar Rp. 13.716,70,- dengan standar deviasi bernilai Rp. 541,624,-. Untuk nilai inflasi terendah sebesar $2,48 \%$ dan inflasi 
tertinggi sebesar 7,26\%, sedangkan rata-rata nilai inflasi sepanjang tahun 2015-2019 sebesar 3,99\%.

\section{Hasil Uji Asumsi Klasik}

Uji asumsi pertama adalah mendeteksi apakah model regresi mengalami gejala autokorelasi yaitu dengan melihat nilai Durbin-Watson (D-W). Berdasarkan hasil output uji autokorelasi dalam Tabel 2, teridentifikasi nilai D-W yaitu 1,242 atau berada di antara -2 dan +2 . Dengan demikian, model regresi yang digunakan dalam penelitian ini dinyatakan terbebas dari gejala autokorelasi.

Uji asumsi kedua adalah uji multikolinieritas, yaitu dengan melihat skor tolerance dan VIF dari setiap variabel bebas terhadap variabel terikat. Berdasarkan hasil output dalam Tabel 2 diperoleh skor tolerance dari ketiga variabel bebas $>0,10$, sedangkan untuk skor VIF dari ketiga variabel bebas < 10. Dengan demikian bisa disimpulkan bahwa model penelitian ini terbebas dari gejala multikolinieritas.
Uji asumsi ketiga adalah uji heteroskedastisitas, yaitu dengan melihat skor Sig. dari setiap variabel independen. Hasil output dalam Tabel 2 menunjukkan skor Sig. variabel Lag_X $X_{1}$ (jumlah uang beredar) sebesar 0,195; skor Sig. variabel Lag_X (kurs) sebesar 0,789; dan, skor Sig. variabel Lag_X $_{3}$ (inflasi) sebesar 0,724. Ketiga skor tersebut adalah lebih besar dari 0,05 maka dapat dinyatakan bahwa model penelitian ini terbebas dari gejala heteroskedastisitas.

Uji asumsi terakhir yaitu uji normalitas, yaitu menginterpretasikan grafik histogram ataupun tampilan Normal P-P Plot. Hasil output pada Gambar 3 menunjukkan diagram histogram yang menyerupai bentuk lonceng, sementara tampilan pada grafik Normal P-P Plot memperlihatkan titik-titik mengikuti arah garis diagonalnya. Berdasarkan interpretasi atas kedua grafik itu maka dapat dinyatakan bahwa data dalam model penelitian ini telah terdistribusi secara normal.

Tabel 1. Hasil Uji Statistik Deskriptif

\begin{tabular}{lcccc}
\hline & Min & Max & Mean & Std. Deviation \\
\hline Harga Beras & 10569 & 12414 & 11621,40 & 465,955 \\
JUB & 4174825,91 & 6136552,00 & 5127984,6255 & 575769,20074 \\
Kurs & 12652 & 15227 & 13716,70 & 541,624 \\
Inflasi & 2,48 & 7,26 & 3,9898 & 1,37212 \\
\hline
\end{tabular}

Sumber: Data sekunder diolah, 2020.

Tabel 2. Hasil Uji Autokorelasi, Multikolinieritas dan Heteroskedastisitas

\begin{tabular}{lcccc}
\hline Durbin-Watson (D-W) & 1,242 & & & \\
\hline & Tolerance & VIF & t & Sig. \\
\hline (Constant) & - & - & 1,477 & 0,146 \\
Lag_JUB & 0,651 & 1,536 & $-1,313$ & 0,195 \\
Lag_Kurs & 0,862 & 1,160 & $-0,269$ & 0,789 \\
Lag_Inflasi & 0,738 & 1,354 & $-0,355$ & 0,724 \\
\hline
\end{tabular}

Sumber: Data sekunder diolah, 2020. 

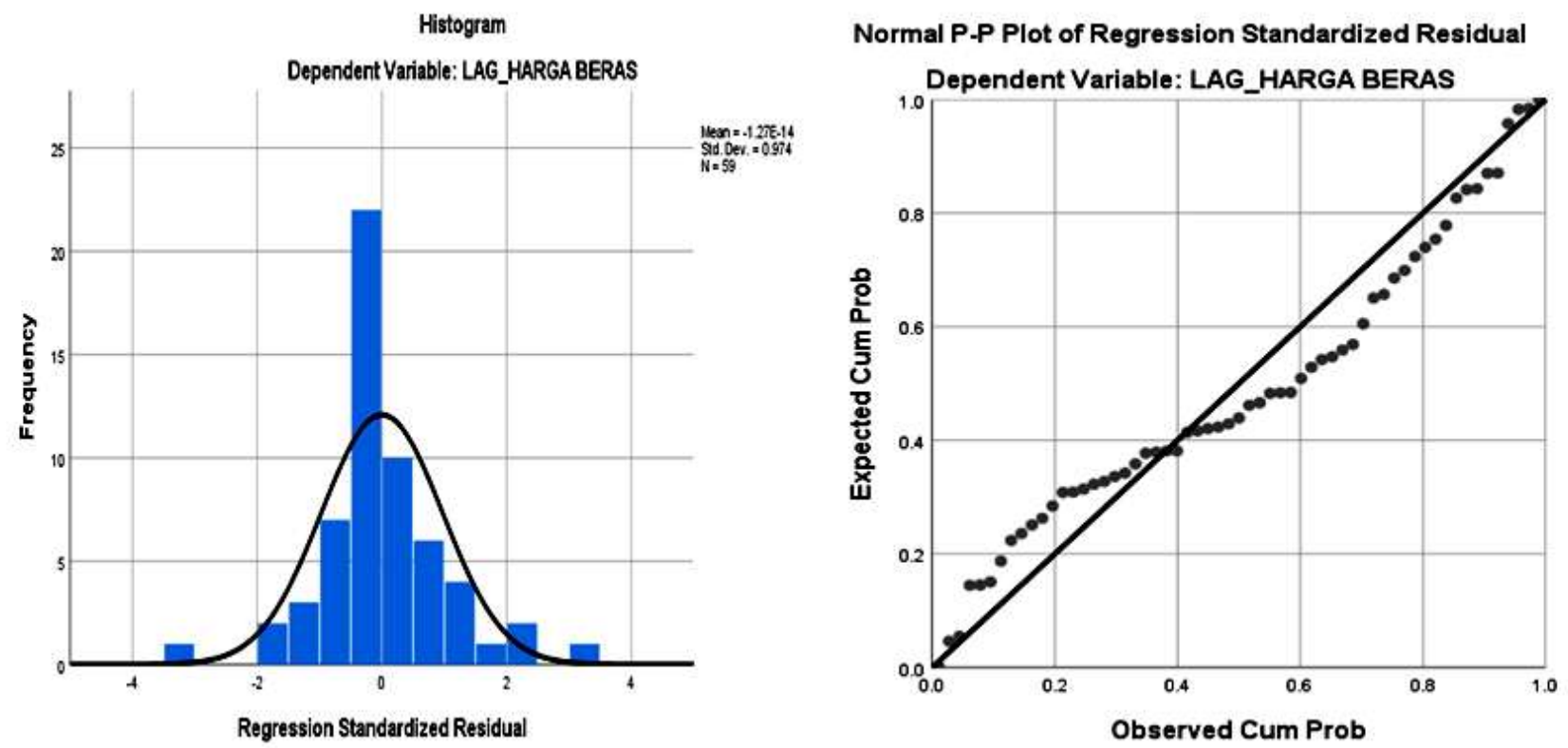

Gambar 3. Hasil Uji Normalitas

Sumber: Data sekunder diolah, 2020.

Tabel 3. Hasil Analisis Regresi Tahap 1

\begin{tabular}{llccccc}
\hline & & \multicolumn{2}{c}{$\begin{array}{c}\text { Unstandardized } \\
\text { Coefficients }\end{array}$} & $\begin{array}{c}\text { Standardized } \\
\text { Coefficients }\end{array}$ & & \\
\cline { 3 - 5 } Model & & $\mathrm{B}$ & Std. Error & Beta & t & Sig. \\
\hline \multirow{2nyyynn}{*}{1} & (Constant) & 6,956 & 2,322 & & 2,996 & 0,004 \\
& Lag_JUB & $-1,835$ & 0,415 & $-0,542$ & $-4,418$ & 0,000 \\
& Lag_Kurs & 0,727 & 0,721 & 0,124 & 1,009 & 0,317 \\
\hline F & $=$ & 9,924 & & & & \\
Sig & $=$ & 0,000 & & & & \\
R Square & $=$ & 0,262 & & & & \\
\hline
\end{tabular}

Sumber: Data sekunder diolah, 2020.

Tabel 4. Hasil Analisis Regresi Tahap 2

\begin{tabular}{llccccc}
\hline & \multicolumn{5}{c}{$\begin{array}{c}\text { Unstandardized } \\
\text { Coefficients }\end{array}$} & \multicolumn{2}{c}{$\begin{array}{c}\text { Standardized } \\
\text { Coefficients }\end{array}$} & & Sig. \\
\cline { 3 - 5 } Model & & B & Std. Error & Beta & t & Sig \\
\cline { 3 - 5 } & (Constant) & 1,965 & 0,259 & & 7,577 & 0,000 \\
& Lag_JUB & 0,199 & 0,050 & 0,497 & 3,986 & 0,000 \\
& Lag_Kurs & $-0,010$ & 0,075 & $-0,015$ &,- 135 & 0,893 \\
& Lag_Inflasi & $-0,031$ & 0,014 & $-0,266$ & $-2,269$ & 0,027 \\
\hline F & $=$ & 14,620 & & & & \\
Sig & $=$ & 0,000 & & & & \\
R Square & $=$ & 0,444 & & & & \\
\hline
\end{tabular}

Sumber: Data sekunder diolah, 2020. 


\section{Analisis Regresi 1 (Sub Struktur 1)}

Berdasarkan hasil output analisis regresi tahap pertama (Tabel 3), maka persamaan regresi pertama dalam penelitian ini adalah:

$$
\text { Inflasi }=6,956-1,835 \mathrm{JUB}+0,727 \text { Kurs }
$$

Persamaan tersebut menyatakan bahwa jumlah uang beredar memiliki pengaruh yang bernilai negatif terhadap inflasi. Dengan kata lain, jika jumlah uang beredar mengalami peningkatan, maka inflasi akan menurun. Sebaliknya, jika jumlah uang beredar (JUB) mengalami penurunan, maka inflasi akan menaik. Kondisi ini diasumsikan terjadi jika kurs memiliki nilai yang konstan.

Di sisi lain, persamaan itu menyatakan bahwa kurs memiliki pengaruh yang bernilai positif terhadap inflasi. Dengan demikian, jika nilai kurs (IDR/USD) menaik, maka inflasi juga akan mengalami kenaikan; sebaliknya jika nilai kurs (IDR/USD) menurun, maka inflasi juga akan mengalami penurunan. Kondisi ini diasumsikan terjadi jika jumlah uang beredar memiliki nilai yang konstan.

\section{Analisis Regresi 2 (Sub Struktur 2)}

Selanjutnya, berdasarkan hasil output analisis regresi tahap kedua (Tabel 4), maka persamaan regresi kedua yang diperoleh dalam penelitian ini adalah:

Harga Beras $=1,965+0,199 \mathrm{JUB}-0,010$ Kurs

$$
-0,031 \text { Inflasi }
$$

Persamaan tersebut menyatakan bahwa jumlah uang beredar memiliki pengaruh yang bernilai positif terhadap harga beras. Artinya, jika jumlah uang beredar meningkat, maka harga beras juga akan meningkat. Sebaliknya, jika jumlah uang beredar (JUB) mengalami penurunan, maka harga beras juga menurun. Kondisi ini diasumsikan terjadi jika kurs dan inflasi memiliki nilai yang konstan.

Berkaitan dengan variabel independen yang kedua, persamaan tersebut menyatakan bahwa kurs memiliki pengaruh yang bernilai negatif terhadap harga beras. Hal ini berarti bahwa jika kurs mengalami peningkatan, maka harga beras akan menurun. Sebaliknya, jika kurs mengalami penurunan, maka harga beras akan meningkat atau bertambah mahal. Kondisi ini diasumsikan terjadi jika jumlah uang beredar dan inflasi memiliki nilai yang konstan atau tidak berubah.

Persamaan itu lebih lanjut menyatakan bahwa inflasi memiliki pengaruh negatif terhadap harga beras. Hal ini berarti bahwa jika inflasi mengalami peningkatan nilai, maka harga beras akan mengalami penurunan. Sebaliknya, jika nilai inflasi mengalami penurunan, maka harga beras akan meningkat. Kondisi ini diasumsikan terjadi jika jumlah uang beredar dan kurs memiliki nilai yang konstan atau tidak berubah.

\section{Hasil Uji Hipotesis}

Berdasarkan hasil output regresi pada Tabel 3 dan Tabel 4, maka dapat dijelaskan pembuktian atas hipotesis-hipotesis yang dikemukakan dalam penelitian ini.

Tabel 3 menunjukkan selama periode 2015-2019, jumlah uang beredar memiliki nilai Sig. $t$ sebesar 0,000 atau lebih kecil dari $0,05(\alpha)$; sehingga hipotesis pertama (H1) yang menyatakan bahwa jumlah uang beredar secara parsial memiliki pengaruh langsung yang signifikan atas inflasi dapat dibuktikan kebenarannya. Tabel 3 juga menunjukkan selama periode 2015-2019, kurs memiliki nilai Sig. $t$ sebesar 0,317 atau lebih besar dari $0,05(\alpha)$; sehingga hipotesis kedua $(\mathrm{H} 2)$ yang menyatakan kurs secara parsial memiliki pengaruh langsung yang signifikan terhadap inflasi tidak dapat dibuktikan kebenarannya.

Berdasarkan Tabel 4 diperoleh selama periode 2015-2019, jumlah uang beredar memiliki nilai Sig. $t$ sebesar 0,000 atau lebih kecil dari $0,05(\alpha)$; sehingga hipotesis ketiga (H3) yang menyatakan bahwa jumlah uang beredar secara parsial berpengaruh signifikan 
atas harga beras bisa terbukti kebenarannya. Berikutnya, kurs diidentifikasi memiliki nilai Sig. $t$ sebesar 0,893 atau lebih besar dari 0,05 $(\alpha)$; sehingga hipotesis keempat (H4) yang menyatakan kurs secara parsial memiliki pengaruh langsung yang signifikan terhadap inflasi tidak dapat dibuktikan kebenarannya. Variabel inflasi pada Tabel 4 diidentifikasi memiliki nilai Sig. $t$ sebesar 0,027 atau lebih kecil dari 0,05 $(\alpha)$; sehingga hipotesis kelima (H5) yang menyatakan inflasi secara parsial memiliki pengaruh langsung yang signifikan atas harga beras bisa terbukti kebenarannya.

Tabel 3 lebih jauh menunjukkan jumlah uang beredar dan kurs secara simultan terbukti berpengaruh signifikan atas inflasi, karena nilai Sig. $F$ sebesar 0,000 lebih kecil dari 0,05. Sementara itu, berdasarkan Tabel 4, jumlah uang beredar, kurs dan inflasi secara simultan terbukti signifikan mempengaruhi harga beras, dimana nilai Sig. F sebesar 0,000 atau lebih kecil dari 0,05 $(\alpha)$.

\section{Hasil Uji Analisis Jalur}

Hasil analisis tentang besaran pengaruh dari jumlah uang beredar dan kurs terhadap harga beras melalui inflasi sebagai variaabeel intervening, ditunjukkan dalam Tabel 5.

Berdasarkan Tabel 5 diperoleh besaran pengaruh langsung dari jumlah uang beredar terhadap harga beras adalah 0,497; pengaruh tidak langsung melalui mediasi inflasi terhadap harga beras adalah 0,144; dan, total pengaruhnya sebesar 0,641. Sementara itu, pengaruh langsung dari kurs terhadap harga beras adalah -0,015; pengaruh tidak langsung melalui mediasi inflasi atas harga beras yaitu $-0,033$; dan, total pengaruhnya sebesar $-0,048$.

Untuk menguji dua hipotesis mediasi (H6 dan H7) maka dilakukan uji Sobel. Uji ini merupakan prosedur yang dikembangkan oleh Sobel untuk menguji kekuatan pengaruh tidak langsung antara variabel-variabel independen atas variabel dependen melalui variabel intervening. Prosedur perhitungan mula-mula untuk menganalisis pengaruh jumlah uang beredar terhadap harga beras melalui inflasi, selanjutnya dilakukan untuk menganalisis pengaruh kurs terhadap harga beras melalui inflasi.

Prosedur pertama adalah menganalisis pengaruh jumlah uang beredar terhadap harga beras melalui inflasi. Proses dimulai dengan menghitung nilai Sobel $(S a b)$, lalu menghitung nilai $t$-statistik atas pengaruh mediasi:

1. Penghitungan Sobel

$$
\begin{aligned}
\mathrm{Sab} & =\sqrt{-0,031^{2} 0,415^{2}+-1,835^{2} 0,014^{2}+0,415^{2} 0,014^{2}} \\
& =0,030 .
\end{aligned}
$$

2. Penghitungan nilai $t$-statistik

$$
\mathrm{t}=\frac{-0,542 \mathrm{x}-0,266}{0,030}=4,806
$$

Berdasarkan penghitungan diperoleh nilai $t$ hitung sebesar 4,805 atau lebih besar dari $t$ tabel $(2,002)$ pada level signifikansi 0,05 . Hal ini berarti inflasi secara signifikan memediasi pengaruh jumlah uang beredar terhadap harga beras. Dengan demikian, hipotesis keenam

\begin{tabular}{|c|c|c|c|}
\hline Variabel & \multicolumn{2}{|c|}{ Jumlah Uang Beredar } & Kurs \\
\hline Pengaruh Langsung & \multicolumn{2}{|c|}{0,497} & $-0,015$ \\
\hline Pengaruh Tidak Langsung & \multicolumn{2}{|c|}{$-0,542 \times-0,266=0,144$} & $0,124 \times-0,266=-0,033$ \\
\hline \multirow[t]{2}{*}{ Pengaruh Total : } & $0,497+0,144$ & $=$ & 0,641 \\
\hline & $-0,015+-0,033$ & $=$ & $-0,048$ \\
\hline
\end{tabular}
(H6) dinyatakan dapat dibuktikan.

Tabel 5. Hasil Analisis Pengaruh Langsung dan Tidak Langsung

Sumber: Data sekunder diolah, 2020. 
Prosedur kedua adalah menganalisis pengaruh kurs terhadap harga beras melalui inflasi. Proses dilakukan seperti halnya pada prosedur pertama, yaitu:

1. Penghitungan Sobel

$$
\begin{aligned}
\mathrm{Sab} & =\sqrt{-0,031^{2} 0,721^{2}+0,727^{2} 0,014^{2}+0,721^{2} 0,014^{2}} \\
& =0,026 .
\end{aligned}
$$

2. Penghitungan nilai $t$-statistik

$$
\mathrm{t}=\frac{0,124 \mathrm{x}-0,266}{0,026}=-1,269
$$

Berdasarkan penghitungan diperoleh nilai $t$ hitung sebesar -1,269 atau lebih kecil dari $t$ tabel $(2,002)$ pada level signifikansi 0,05 . Hal ini berarti bahwa inflasi tidak memediasi pengaruh kurs terhadap harga beras. Dengan demikian, hipotesis ketujuh (H7) dinyatakan tidak terbukti.

\section{Pembahasan}

\section{Pengaruh Jumlah Uang Beredar terhadap Inflasi}

Hasil penelitian ini menunjukan jumlah uang beredar berpengaruh secara negatif dan signifikan terhadap inflasi. Artinya, apabila volume uang beredar meningkat maka inflasi akan mengalami penurunan. Hasil temuan ini mengafirmasi penelitian yang dilakukan oleh Lim \& Sek (2015) serta Ningsih \& Kristiyanti (2018) yang di dalam studinya memperoleh temuan serupa.

Terdapat beberapa dugaan berkaitan pengaruh negatif dari jumlah uang beredar atas inflasi ini. Pertama, karena peredaran uang pada rentang tahun 2015-2019 tidak terlalu mengalami kenaikan yang sangat signifikan, sehingga perputaran uang yang terjadi dipandang tidak memengaruhi laju inflasi. Dugaan kedua yaitu persentase uang kuasi pada tahun penelitian cenderung memiliki angka yang relatif tinggi, sedangkan nilai dari uang kuasi sendiri tidak likuid, sehingga walaupun level persentasenya relatif tinggi, tidak cukup untuk dapat memengaruhi inflasi (Utami \& Soebagiyo, 2013).

\section{Pengaruh Kurs terhadap Inflasi}

Temuan penelitian ini menunjukan bahwa kurs berpengaruh positif dan tidak signifikan atas inflasi. Hasil ini menyatakan apabila nilai tukar rupiah terhadap dollar melemah akan berdampak terhadap naiknya tingkat inflasi.

Pengaruh yang tidak signifikan dari kurs terhadap inflasi itu disebabkan karena kurs rupiah terhadap dollar Amerika pada rentang tahun yang diteliti menunjukkan aktivitas fluktuasi tidak terlalu signifikan, sehingga melemah ataupun menguatnya kurs tidak akan terlalu berdampak terhadap laju inflasi. Hasil ini mendukung penelitian Madesha et al. (2013) yang juga menemukan bahwa nilai tukar tidak akan menimbulkan tekanan atas inflasi. Meskipun kurs tidak berdampak signifikan terhadap inflasi, pemerintah harus tetap selalu menjaga stabilitas nilai tukar. Karena jika kurs rupiah terhadap dollar terus melemah akan berdampak terhadap tingkat harga domestik yang mencerminkan tingkat inflasi (Langi et al., 2014).

\section{Pengaruh Jumlah Uang Beredar terhadap Harga Beras}

Temuan penelitian ini menyatakan jumlah uang beredar berpengaruh positif dan signifikan terhadap harga beras. Hasil ini mengidentifikasikan bahwa kenaikan jumlah uang beredar akan berpengaruh terhadap naiknya harga beras.

Hasil riset ini memperluas temuan Putra (2014) bahwa harga pangan dipengaruhi secara positif dan signifikan oleh jumlah uang beredar (M2). Disamping itu, hasil ini juga sejalan dengan teori kuantitas uang, dimana peredaran uang yang terlalu berlebihan akan menimbulkan purchasing power yang tinggi di dalam masyarakat. Kondisi ini dinilai dapat 
menyebabkan permintaan yang berlebihan dan selanjutnya berdampak pada kenaikan harga-harga dari barang dan jasa.

\section{Pengaruh Kurs terhadap Harga Beras}

Hasil penelitian ini membuktikan bahwa kurs berpengaruh negatif dan tidak signifikan terhadap harga beras. Koefisien negatif yang dimiliki kurs mengindikasikan bahwa jika nilai tukar menguat maka akan menyebabkan penurunan terhadap harga beras; sebaliknya, jika nilai tukar terdepresiasi maka harga beras akan mengalami kenaikan.

Hasil analisis ini sejalan dengan teori paritas daya beli, dimana seharusnya nilai tukar antar dua mata uang sama dengan rasio tingkat harga kedua negara (Taylor \& Taylor, 2004). Meningkatnya laju inflasi suatu negara dapat disebabkan oleh menurunnya daya beli domestik suatu mata uang yang diiringi dengan menyusutnya nilai mata uang negara tersebut. Sebaliknya, jika terjadi apresiasi mata uang akan menimbulkan deflasi akibat dari meningkatnya daya beli.

\section{Pengaruh Inflasi terhadap Harga Beras}

Penagruh inflasi terhadap harga beras dibuktikan dalam penelitian ini berpengaruh negatif dan signifikan, sehingga naiknya laju inflasi akan menurunkan harga beras pada periode tahun 2015-2019.

Hasil analisis ini sejalan dengan temuan riset milik Setyoaji et al. (2014) yang mengungkapkan bahwa inflasi berpengaruh secara signifikan terhadap harag beras. Sama halnya dengan temuan studi milik Muljawan \& Alibaba (2009), bahwa tingkat inflasi berpengaruh nyata terhadap harga beras. Namun demikian, fluktuasi inflasi yang terjadi selama periode pengamatan ini dinilai masih pada kategori inflasi rendah, sehingga tidak memiliki potensi menimbulkan gejolak perekonomian yang berlebihan.

\section{Pengaruh Mediasi melalui Inflasi}

Hasil analisis pengaruh mediasi dalam penelitian ini menemukan bahwa inflasi mampu memediasi jumlah uang beredar terhadap harga beras secara positif dan signifikan. Temuan ini mengindikasikan bahwa semakin tinggi nilai jumlah uang beredar akan berpengaruh terhadap kenaikan harga beras yang dimediasi oleh inflasi.

Hasil analisis dalam penelitian ini juga menemukan tidak adanya bukti bahwa inflasi memediasi pengaruh kurs terhadap harga beras periode 2015-2019. Temuan ini mengindikasikan bahwa meningkatnya nilai kurs tidak berpengaruh terhadap kenaikan harga beras bila dimediasi oleh tingkat inflasi.

\section{SIMPULAN}

Temuan-temuan yang diperoleh dalam penelitian ini memunculkan beberapa kesimpulan. Pertama, jumlah uang beredar berpengaruh negatif dan signifikan terhadap inflasi, namun berpengaruh positif dan signifikan terhadap harga beras. Kedua, kurs berpengaruh positif dan tidak signifikan terhadap inflasi, namun berpengaruh negatif dan tidak signifikan terhadap harga beras. Ketiga, inflasi secara parsial dan independen berpengaruh negatif dan signifikan terhadap harga beras; tetapi selaku variabel intervening hanya memediasi jumlah uang beredar terhadap harga beras.

Temuan penelitian ini lebih lanjut dapat dijadikan pertimbangan oleh pemerintah khususnya terkait masalah pengaturan jumlah uang beredar, karena jika jumlahnya tidak terkendali maka dapat memicu kenaikan inflasi dan berimbas pada kenaikan hargaharga komoditas seperti beras. Selain itu, stabilisasi nilai tukar atau kurs juga harus selalu diperhatikan guna menjaga stabilitas perekonomian. 
Terakhir, temuan ini memunculkan rekomendasi bagi para peneliti lanjutan, yang diharapkan memperbanyak jumlah analisis data dari variabel-variabel lain yang dinilai memiliki keterkaitan dengan harga beras, dan memperluas periode penelitian sehingga mencakup rentang waktu yang lebih panjang atau lama sehingga hasil analisis yang diperoleh dinilai lebih sesuai.

\section{REFERENSI}

Adhawiyah, R., Prajawati, M. I., \& Firdian, R. (2018). Pengaruh paritas daya beli, paritas suku bunga terhadap nilai tukar rupiah dan dollar Amerika Serikat. Iqtishoduna, 14(1), 55-70. doi: 10.18860/iq.v0i0.4839.

Browne, F., \& Cronin, D. (2010). Commodity prices, money and inflation. Journal of Economics and Business, 62(4), 331345. doi: 10.1016/j.jeconbus.2010.02. 003.

Eiteman, D. K., Stonehill, A. I., \& Moffett, M. H. (2010). Manajemen keuangan multinasional. Edisi terjemahan, edisi kesebelas. Erlangga.

Faris, M. I. Z. A. (2016). Analisis pengaruh nilai tukar, inflasi, jumlah uang beredar (jub), produksi kedelai dalam negeri dan volume impor kedelai terhadap harga domestik komoditas kedelai. Skripsi (tidak dipublikasikan), Universitas Islam Negeri Sunan Kalijaga. Retrieved from http://digilib. uin-suka.ac.id/24918/.

Ghozali, I. (2018). Aplikasi analisis multivariat dengan program IBM SPSS 25, Badan Penerbit-Undip.

Gilbert, C. L. (2010). How to understand high food prices. Journal of Agricultural Economics, 61(2), 398-425. doi: 10.1111/j.1477-9552.2010.00248.x.

Hayes, A. F. (2009). Beyond Baron and Kenny: Statistical mediation analysis in the new millennium. Communication Monographs, 76(4), 408-420. doi: $10.1080 / 03637750903310360$.
Jumhur, J., Nasrun, M. A., Agustiar, M., \& Wahyudi. (2018). Pengaruh jumlah uang beredar, ekspor dan impor terhadap inflasi (Studi empiris pada perekonomian Indonesia). Jurnal Ekonomi Bisnis dan Kewirausahaan, 7(3), 186-201. doi: 10.26418/jebik. v7i3.26991.

Langi, T. M., Masinambow, V., \& Siwu, H. (2014). Analisis pengaruh suku bunga bi, jumlah uang beredar, dan tingkat kurs terhadap tingkat inflasi di Indonesia. Jurnal Berkala Ilmiah Efisiensi, 14(2), 44-58. Retrieved from https://ejournal.unsrat.ac.id/index.php/j bie/article/view/4184/3713.

Larasati, D. M., \& Amri, A. (2017). Pengaruh tingkat suku bunga sertifikat Bank Indonesia dan nilai tukar terhadap inflasi di Indonesia. Jurnal Ilmiah Mahasiswa Ekonomi Pembangunan, 2(4), 535-543. Retrieved from http:// www.jim.unsyiah.ac.id/EKP/article/vie $w / 5728$.

Lim, Y. C., \& Sek, S. K. (2015). An examination on the determinants of inflation. Journal of Economics, Business and Management, 3(7), 678682. doi: 10.7763/JOEBM.2015.V3. 265.

Madesha, W., Chidoko, C., \& Zivanomoyo, J. (2013). Empirical test of the relationship between exchange rate and inflation in Zimbabwe. Journal of Economics and Sustainable Development, 4(1), 52-59. Retrieved from https://www.iiste.org/Journals/ index.php/JEDS/article/view/4096.

Mahendra, A. (2016). Analisis pengaruh jumlah uang beredar, suku bunga sbi dan nilai tukar terhadap inflasi di Indonesia. JRAK: Jurnal Riset Akuntansi dan Keuangan, 2(1), 1-12. doi: 10.1234/akuntansi.v2i1.170.

Malian, A. H., Mardianto, S., \& Ariani, M. (2004). Faktor-faktor yang mempengaruhi produksi, konsumsi dan harga beras serta inflasi bahan makanan. Jurnal Agro Ekonomi, 22(2), 119-146. doi: 10.21082/jae.v22n2.2004.119-146. 
Maune, A., Matanda, E., \& Mundonde, J. (2020). Is money supply the cause of inflation in Zimbabwe? An empirical examination. Acta Universitatis Danubius. Economica, 16(3), 17-37. Retrieved from https://dj.univdanubius.ro/index.php/AUDOE/article/ view/372.

Mbongo, J. E., Mutasa, F., \& Msigwa, R. E. (2014). The effects of money supply on inflation in Tanzania. Economics, 3(2), 19-26. doi: 10.11648/J.ECO.20140302. 11.

Muljawan, R. E., \& Alibaba, R. B. (2009). Faktor-faktor yang mempengaruhi harga beras di Jawa Timur. Buana Sains, 9(2), 111-118. doi: 10.33366/bs. v9i2.230.

Namira, Y., Nuhung, I. A., \& Najamuddin, M. (2017). Analisis faktor-faktor yang mempengaruhi impor beras di Indonesia. Jurnal Agribisnis, 11(2), 183-201. doi: 10.15408/aj.v11i2.11843.

Ningsih, S., \& Kristiyanti, L. M. S. (2018). Analisis pengaruh jumlah uang beredar, suku bunga, dan nilai tukar terhadap inflasi di Indonesia periode 2014-2016. Daya Saing: Jurnal Ekonomi Manajemen Sumber Daya, 20(2), 96103. doi: 10.23917/dayasaing.v20i2. 7258.

Nopirin. (2000). Ekonomi moneter. BPFEUGM.

Perlambang, H. (2012). Analisis pengaruh jumlah uang beredar, suku bunga SBI, nilai tukar terhadap tingkat inflasi. Media Ekonomi, 19(2), 49-68. doi: 10.25105/me.v18i2.2251.

Putra, M. I. (2014). Determinasi kenaikan harga pangan di Indonesia (Pangan padi, kedelai periode 2001-2011). Jurnal Imliah Mahasiswa FEB Universitas Brawijaya, 3(1), 1-16. Retrieved from https://jimfeb.ub.ac.id/ index.php/jimfeb/article/view/1387.

Putra, Y. P. (2017). Analisis pengaruh harga beras, produksi beras dan PDRB terhadap inflasi di Indonesia tahun 2010 - 2015. Jurnal Ilmiah Mahasiswa FEB
Universitas Brawijaya, 5(2), 1-24. Retrieved from https://jimfeb.ub.ac.id/ index.php/jimfeb/article/view/5368.

Radjab, E., \& Jam'an, A. (2017). Metode penelitian bisnis $\left(1^{\text {st }}\right.$ ed.), Lembaga Perpustakaan dan Penerbitan Universitas Muhammadiyah Makassar.

Rahadyan, H., \& Lubis, A. (2018). Monetary integration in the ASEAN economic community challenge: The role of the exchange rate on inflation in Indonesia. International Journal of Services, Technology and Management, 24(5-6), 463-479. doi: 10.1504/IJSTM.2018. 094438.

Rahmanta, \& Maryunianta, Y. (2020). Pengaruh harga komoditi pangan terhadap inflasi di kota Medan. Jurnal Agrica, 13(1), 35-44. doi: 10.31289/ agrica.v13i1.3121.

Rahmawati, D., Hidayat, W., \& Susilowati, D. (2017). Analisis pengaruh suku bunga sertifikat Bank Indonesia dan jumlah uang beredar terhadap tingkat inflasi di Indonesia periode 2006-2015 (Pendekatan error correction model). Jurnal Ilmu Ekonomi, 1(2), 240-254. Retrieved from https://ejournal.umm. ac.id/index.php/jie/article/view/5409.

Rezitis, A. N. (2015). The relationship between agricultural commodity prices, crude oil prices and US Dollar exchange rates: A panel VAR approach and causality analysis. International Review of Applied Economics, 29(3), 403-434. doi: 10.1080/02692171. 2014.1001325.

Saputra, A., Arifin, B., \& Kasymir, E. (2014). Analisis kausalitas harga beras, harga pembelian pemerintah (HPP) dan inflasi serta efektivitas kebijakan HPP di Indonesia. Jurnal Ilmu Ilmu Agribisnis, 2(1), 24-31. doi: 10.23960/ jiia.v2i1.24-31.

Setyoaji, S. B., Hani, E. S., \& Sunartomo, A. F. (2014). Faktor-faktor yang mempengaruhi fluktuasi harga beras IR-64 premium 2015-2020 di Jawa Timur. Berkala Ilmiah Pertanian, 1-11. 
Retrieved from http://repository.unej. ac.id/handle/123456789/69517.

Suarsih, S., Achasin, N. A., \& Nuryartono, N. (2016). Dampak perubahan nilai tukar terhadap indeks harga konsumen bahan makanan di Indonesia. Jurnal Ekonomi dan Pembangunan Indonesia, 17(1), 114. doi: 10.21002/jepi.v17i1.548.

Suharjo, B. (2013). Statistika terapan disertai contoh aplikasi dengan SPSS, Graha Ilmu.

Taylor, A. M., \& Taylor, M. P. (2004). The purchasing power parity debate. Journal of Economic Perspectives, 18(4), 135-158. doi: 10.1257/08953300 42632744.
Utami, A. T., \& Soebagiyo, D. (2013). Penentu inflasi di Indonesia; Jumlah uang beredar, nilai tukar, ataukah cadangan devisa?. Jurnal Ekonomi \& Studi Pembangunan, 14(2), 144-152. Retrieved from https://journal.umy. ac.id/index.php/esp/article/view/1266/ 1321. 